\title{
A hierarchical climatic zoning method for energy efficient building design applied in the region with diverse climate characteristics
}

Article

Accepted Version

Creative Commons: Attribution-Noncommercial-No Derivative Works 4.0

Xiong, J., Yao, R., Grimmond, S., Zhang, Q. and Li, B. (2019) A hierarchical climatic zoning method for energy efficient building design applied in the region with diverse climate characteristics. Energy and Buildings, 186 (2019). pp. 355367. ISSN 0378-7788 doi:

https://doi.org/10.1016/j.enbuild.2019.01.005 Available at https://centaur.reading.ac.uk/82112/

It is advisable to refer to the publisher's version if you intend to cite from the work. See Guidance on citing.

To link to this article DOI: http://dx.doi.org/10.1016/j.enbuild.2019.01.005

Publisher: Elsevier

All outputs in CentAUR are protected by Intellectual Property Rights law, including copyright law. Copyright and IPR is retained by the creators or other copyright holders. Terms and conditions for use of this material are defined in the End User Agreement. 


\section{www.reading.ac.uk/centaur}

\section{CentAUR}

Central Archive at the University of Reading

Reading's research outputs online 
A hierarchical climatic zoning method for energy efficient building design applied in the region with diverse climate characteristics Jie Xiong ${ }^{\mathrm{a}, \mathrm{c}, \mathrm{d}}$, Runming Yao ${ }^{\mathrm{a}, \mathrm{c}, *}$, Sue Grimmond ${ }^{\mathrm{d}}$, Qiulei Zhang ${ }^{\mathrm{a}, \mathrm{b}}$, Baizhan $\mathrm{Li}^{\mathrm{a}, \mathrm{b}, *}$

ajoint International Research Laboratory of Green Buildings and Built Environments (Ministry of Education), Chongqing University, Chongqing 400045, Chine b National Centre for International Research of Low-carbon and Green Buildings (Ministry of Science and Technology), Chongqing University, Chongqing 400045, China

'School of the Built Environment, University of Reading, Reading RG6 6DF, UK d Department of Meteorology, University of Reading, Reading RG6 6BB, UK

\section{A hierarchical climatic zoning method for energy efficient building design} applied in the region with diverse climate characteristics

${ }^{1}$ Joint International Research Laboratory of Green Buildings and Built Environments (Ministry of Education),

Chongqing University, Chongqing 400045, China

$9 \quad{ }^{2}$ National Centre for International Research of Low-carbon and Green Buildings (Ministry of Science and Technology),

10 Chongqing University, Chongqing 400045, China

$11{ }^{3}$ School of the Built Environment, University of Reading, Reading RG6 6DF, UK

$12{ }^{4}$ Department of Meteorology, University of Reading, Reading RG6 6BB, UK

13 *Corresponding author: r.yao@ reading.ac.uk; baizhanli@cqu.edu.cn

\section{Abstract}

The climate-responsive strategies for energy efficient building design and management require a detailed understanding of the local climatic conditions, while climate zones are fundamental to building regulations and the application of technologies. Smaller and more homogeneous climate zones could help policy-makers and building designers to improve building energy efficiency while improving the indoor thermal environment. A new climate zoning method, with two-tier 

0

classification designed for passive building design, is proposed, using climate data (degree-days, relative humidity, solar radiation and wind speed) with Hierarchical Agglomerative Clustering (HAC) following the Ward's method. The method is applied to the Hot Summer and Cold Winter $(H S C W)$ zone of China as a showcase, where there are no fine climate zones for energy efficient building design with diverse climate characteristics. Seven sub-zones that consider both cooling and heating demands are generated in Tier 1. In the second tier, the HSCW zone is further sub-divided into three humidity groups, three solar radiation clusters, and four wind speed clusters. To assess the impact of climate zoning on building heating and cooling, EnergyPlus simulations are conducted with the output of heating and cooling load. The cooling loads decrease from sub-zone A to B to C $\left(\right.$ mean $=82.8,65.3,43.8 \mathrm{kWh} \mathrm{m}^{-2}$, respectively) with sub-zone mean heating A1 larger than A2 and A3, B1 larger than B2, and C1 larger than C2, which is in accordance with the assumption made in the first-tier division. The higher wind speeds can raise the possibility of natural ventilation, and further increase the free-running period (FRP) when heating and cooling are not needed. The proposed zones are mapped and provide a useful reference for the policy/building code makers for heating and cooling strategies in this region. The method to create the climate zones could be applied in any region with local climate data.

Keywords: Climatic zoning; Energy efficient building design; Hierarchical Agglomerative Clustering (HAC); Passive design; Hot Summer and Cold Winter (HSCW) zone

\section{Highlights}

- New climate zoning method to help improve building energy designs

- Method applicable to diverse climates and will enhance natural resource utilisation

- Method demonstrated in the HSCW zone of China

- Hierarchical Agglomerative Clustering using 166 weather stations (10 years)

- New HSCW sub-zones allow improved spatial resolution of heating/cooling loads 


\section{Acronyms}

$\begin{array}{ll}C D D & \text { Cooling Degree-Days } \\ H A C & \text { Hierarchical Agglomerative Clustering } \\ H D D & \text { Heating Degree-Days } \\ H S C W & \text { Hot Summer and Cold Winter zone } \\ H V A C & \text { Heating, Ventilation and Air-Conditioning } \\ I Q R & \text { Inter-quartile range } \\ R a & \text { Incoming solar radiation } \\ R H & \text { Relative humidity } \\ W S & \text { Wind speed }\end{array}$

\section{Nomenclature}

$C D D 26$

$C_{Z} \frac{d T_{Z}}{d t}$

D

$d_{T \leqslant 5}$

$d_{T \geqslant 25}$

HDD18

$\dot{m}_{\text {inf }} C_{p}\left(T_{\infty}-T_{z}\right)$

$n$

$\dot{Q}_{\text {sys }}$

$T_{a v}$

$T_{a v, \max }$

$T_{i}$

$T_{B, C}$
Cooling Degree-Days $\left(\right.$ base $\left.=26{ }^{\circ} \mathrm{C}\right)\left({ }^{\circ} \mathrm{C}\right)$

Energy stored in zone air (W)

Squared Euclidean distance of a variable

Number of days daily mean temperature $\leq 5^{\circ} \mathrm{C}$

Number of days daily mean temperature $\geq 25{ }^{\circ} \mathrm{C}$

Heating Degree-Days (base $\left.=18^{\circ} \mathrm{C}\right)\left({ }^{\circ} \mathrm{C}\right)$

Heat transfer due to infiltration of outside air

Total number of stations in each cluster

The output from mechanical systems (W)

Monthly mean air temperature $\left({ }^{\circ} \mathrm{C}\right)$

Monthly mean of daily maximum air temperature $\left({ }^{\circ} \mathrm{C}\right)$

Daily average temperature $\left({ }^{\circ} \mathrm{C}\right)$

Base temperature for $\mathrm{CDD}\left(=26^{\circ} \mathrm{C}\right)$ 


$\begin{array}{ll}T_{B, H} & \text { Base temperature for } \operatorname{HDD}\left(=18^{\circ} \mathrm{C}\right) \\ v & \text { Daily mean of a variable } \\ \sum_{i=1}^{N_{\text {surfaces }}} h_{i} A_{i}\left(T_{s i}-T_{z}\right) & \text { Convective heat transfer from the zone surfaces }(\mathrm{W}) \\ \sum_{i=1}^{N_{z o n e s}} \dot{m}_{i} C_{p}\left(T_{z i}-T_{z}\right) & \text { Heat transfer due to inter-zone air mixing }(\mathrm{W}) \\ \sum_{i=1}^{N_{s l}} \dot{Q}_{i} & \text { Total convective internal load }(\mathrm{W})\end{array}$

\section{Subscripts}

$i, j, k$

The identity of a station (or a cluster)

The identity of a new cluster formed from two existing stations (or

(ij) clusters)

$i j, i k, j k,(i j) k$

Connection between two stations (or clusters)

$t$

Time

\section{Introduction}

As excessive energy consumption contributes to climate change $[1,2]$ and air pollution $[3,4]$, governments from most countries have reached consensus to reduce carbon emissions. At the Paris Conference on Climate Change 2015, China pledged that their $\mathrm{CO}_{2}$ emissions would peak around 2030, and to reduce $\mathrm{CO}_{2}$ emission by $60-65 \%$ of the 2005 level [5]. As buildings account for about $40 \%$ of European [6] and 27.5\% of China [7] total energy consumption, energy efficient building design is paramount if the carbon reduction target is to be met.

Passive building design can permit energy efficient and "healthy" architecture design to maximise occupants' comfort and health by harmonizing local climates and site conditions with architectural design and building technologies [8]. The principle is based on climate-responsive strategies taking advantage of natural resources like sunlight and wind while avoiding exposure to heat and cold from the surroundings and excessive radiation, so effective passive design requires a detailed understanding of the local climatic conditions. The adaptability of building energy- 
efficiency technologies varies with geographic locations [9-14]. Modifying passive technologies, including variations in insulation [15-19], natural ventilation [20-22], shading [23,24] and solar space heating [14,25], can effectively reduce energy demands for heating and cooling of buildings. When establishing energy conservation regulations, it is essential to be aware of local climate characteristics. Climatic zoning allows 1) regulation of some thermal properties of a building (e.g. shape coefficient, U-values (wall, roof, glazing), window to wall ratio); 2) overall energy savings targets of the optimally-designed building compared with a baseline scenario; 3) annual energy consumption quotas. China considered the first two in their current standards when a design scheme cannot meet specific limitations perfectly. The total energy consumption of a design scheme and a baseline scenario were calculated to provide a comparison for decisions [26,27]. France specified the maximum energy consumption per unit floor area for each climate zone in their standard, as part of their near-zero energy building in 2020 target [28].

Climate zoning is the preliminary work to establish the building regulations for energy efficiency for most countries. As China's (land area $=9.6$ million $\mathrm{km}^{2}$ ) mainland extends from $21^{\circ} \mathrm{N}$ to $54^{\circ} \mathrm{N}$, and $74^{\circ} \mathrm{E}$ to $135^{\circ} \mathrm{E}$, the climate is diverse: subtropical in the south to the temperate in the north (Figure 1). The Ministry of Housing and Urban-Rural Development of China's (MOHURD) GB 50176-93 Thermal Design Code for Civil Building is a national standard to match regional climates with thermal design of buildings whilst ensuring compliance with basic indoor thermal environment requirements. This standard defines five zones based on climatic conditions (Figure 1a): Severe Cold (SC), Cold (C), Hot Summer and Cold Winter (HSCW), Hot Summer and Warm Winter (HSWW) and Temperate (T). 


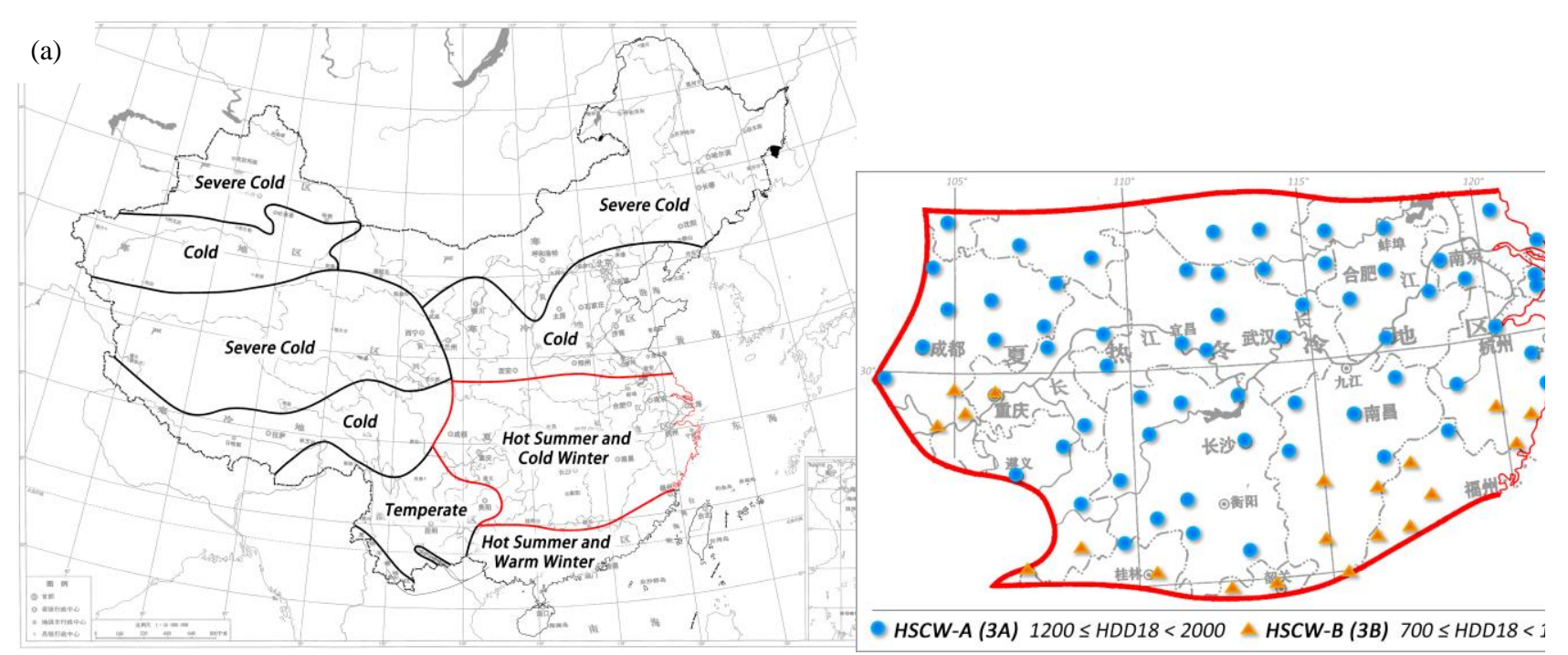

Figure 1: Climate zones for building thermal design (a) for China and (b) the Hot Summer and Cold Winter zone with cities location (dots) in sub-zones 3A (blue) and 3B (orange) (Modified from [29,30])

Improved energy efficiency policies can be obtained from more detailed zoning. For example in the USA at the national level, zoning is by state based on thermal (0-8) and moisture (Moist, Dry and Marine) conditions creating 19 climate zones [31]. To provide more guidance the California Energy Commission uses 16 zones derived primarily from 600 weather stations mean summer and winter temperatures [32,33]. Australia's 8 climate zones [34] are divided by the Nationwide House Energy Rating Scheme (NatHERS) into 69 climate zones [35]. The maximum permissible energy loads and energy performance ratings in different climate zones are various [36], allowing comparison of buildings in different weather conditions across Australia.

To improve the indoor thermal environment, energy is used for heating and cooling. The amount used varies with climate and living standards. The objective of passive design is to account for the outdoor climate to improve indoor comfort while reducing energy consumption; i.e. extend the free-running period (FRP) when heating and cooling are not used [37]. Given the paucity of studies of climatic dynamics impact on passive design, metrics improved climate zones should enhance: building energy efficiency regulations, indoor thermal comfort and energy efficiency.

The objective of this paper is to present a new method to generate climate zones for building energy design. Variables relevant to passive design, including temperature, relative humidity, solar 
radiation and wind [38] are used. However, for a region with diverse climate characteristics, as more variables are considered, greater spatial heterogeneity becomes evident creating potential problems for operational policy and building code. This work aims to efficiently category this region with climate characteristics from historical observation data. To create homogeneous zones, a two-tier approach is taken: first, thermal properties based on heating degree days (HDD) and cooling degree days (CDD); and second, relative humidity, solar radiation and wind speed variables are used. The latter impact specific passive materials or technologies for design. The method is applied to the Hot Summer and Cold Winter zone of China as a showcase. The implications of the proposed sub-zones to typical residential building energy needs are assessed.

\subsection{Climate classification for building design}

The success of early climate classifications based on climate response features related to vegetation [39] (e.g. the well-known Köppen system [40,41]) has prompted their use for building energy standards. Olgyay [42] analysed the influence of climate on building design and suggested four main climate types, i.e. cool, temperate, hot and arid, and hot and humid in the early 1960s. Subsequently, Givoni [38] proposed four major climates, i.e. hot, warm-temperate, cool-temperate and cold, based on the influences of climatic features on human comfort and the thermal performance of buildings. According to the distinct climate characteristics, climate zones have been created using various techniques, including classification [29,31,34,43-50] and clustering $[43,51,52]$, in different regions of the world.

Classification uses manual training to create the divisions. Some countries (e.g. China [29], United States [31], Australia [34] and Japan [44]) select variables to characterize the diversity of their climates and then create the climate zones using subjective thresholds. Most commonly mean air temperature (at $1.5 \mathrm{~m}$ above ground level) is the primary efficacy variable used for building energy performance climate zones (Table 1) [53]. Often degree-days, defined as the sum of positive differences relative to a base temperature over time [54], are used as an alternative of temperature for the consideration of both heating and cooling needs, and it is most relative to energy 
consumption due to space heating and cooling [54]. While temperature based metrics cannot reflect the whole understanding of the climate and its impacts on the building energy consumptions [55], it was often applied in combination with other climate variables. India's five-zone classification considers temperature and relative humidity as two comfort-related factors $[45,46]$. Although Dash et al. [56] propose seven zones for India based on solar radiation and air temperature, with the criteria of considering both weather conditions and solar photovoltaic production. The Spanish Climatic Severity Index (CSI) [57] (as cited in [48]), based on the heating and cooling demands relative to the same building in a reference location, creates 16 regions from five winter and four summer climate zones [47]. Furthermore, the CSI is characterised by climatic variables including degree-days based on $20^{\circ} \mathrm{C}$ (HDD20 or CDD20) and sunshine hours relative to the maximum possible [48,49]. When Verichev and Carpio's [58] apply the Spanish CSI method to Chile, and three zones are identified. Morocco has been subdivided using winter degree days and summer degree days, and 6 climate zones are identified with the aid of simulation results of the annual

Table 1: Variables used in national building standards to identify climate zones include air temperature (T), heating and cooling requirements of buildings in eleven representative cities [50]. monthly mean $\mathrm{T}\left(\mathrm{T}_{\mathrm{av}}\right)$, monthly mean of daily max $\mathrm{T}\left(\mathrm{T}_{\mathrm{av}, \max }\right)$, number of days $\mathrm{T}_{\mathrm{av}} \leq 5^{\circ} \mathrm{C}\left(\mathrm{d}_{\mathrm{T} \leq 5}\right)$ or $\mathrm{T}_{\mathrm{av}} \geq 25$ ${ }^{\circ} \mathrm{C}\left(\mathrm{d}_{\mathrm{T} \geq 25}\right)$, cooling/heating degree-days (CDD/HDD) and relative humidity $(\mathrm{RH})$

\begin{tabular}{|c|c|c|c|c|c|}
\hline \multirow{2}{*}{$\begin{array}{l}\text { Country } \\
\text { [ref] }\end{array}$} & \multirow{2}{*}{$\begin{array}{l}\text { Zone numbers } \\
\text { and names }\end{array}$} & \multicolumn{3}{|l|}{\begin{tabular}{|l|} 
Variables \\
\end{tabular}} & \multirow[t]{2}{*}{ Considers } \\
\hline & & Temperature & DD & Moisture & \\
\hline $\begin{array}{l}\text { China } \\
{[29,30]}\end{array}$ & $\begin{array}{l}\text { 5: SC, C, HSCW, } \\
\text { HSWW, T }\end{array}$ & $\begin{array}{l}\mathrm{T}_{\mathrm{av}} \text { coldest month } \\
\mathrm{T}_{\mathrm{av}} \text { hottest month } \\
\mathrm{d}_{\mathrm{T} \leq 5} \\
\mathrm{~d}_{\mathrm{T}>25}\end{array}$ & $\begin{array}{l}\text { CDD26 } \\
\text { HDD18 }\end{array}$ & --- & Building thermal performance in winter and summer \\
\hline $\begin{array}{l}\text { US } \\
{[31]}\end{array}$ & $\begin{array}{l}\text { 19: } 9 \text { thermal, } 3 \\
\text { moisture }\end{array}$ & $\begin{array}{l}\mathrm{T}_{\mathrm{av}} \\
\text { Annual } \mathrm{T}_{\mathrm{av}}\end{array}$ & $\begin{array}{l}\text { CDD10 } \\
\text { HDD18 }\end{array}$ & $\begin{array}{l}\text { Annual } \\
\text { precipitation }\end{array}$ & Heating and cooling demands together with moisture \\
\hline $\begin{array}{l}\text { Australia } \\
\text { [34] }\end{array}$ & 8 & $\begin{array}{l}\mathrm{T}_{\mathrm{av}, \max } \text { January } \\
\mathrm{T}_{\mathrm{av}} \text { July }\end{array}$ & $\begin{array}{l}\text { Average } \\
\text { annual } \\
\text { HDD }\end{array}$ & $\begin{array}{l}\text { Average } 3 \\
\text { pm January } \\
\text { vapour } \\
\text { pressure }\end{array}$ & $\begin{array}{l}\text { Heating demands } \\
\text { cooling demands focus on extreme heat }\end{array}$ \\
\hline Japan [44] & 8 & --- & HDD18 & --- & Heating demands only \\
\hline $\begin{array}{l}\text { India } \\
{[45,46]}\end{array}$ & $\begin{array}{l}\text { 5: hot-dry, warm- } \\
\text { humid, composite, } \\
\text { temperate, cold }\end{array}$ & $\mathrm{T}_{\mathrm{av}}$ & --- & $\begin{array}{l}\text { Mean } \\
\text { monthly RH }\end{array}$ & Extreme of two comfort-related factors \\
\hline $\begin{array}{l}\text { Spain } \\
{[47-49]}\end{array}$ & $\begin{array}{l}\text { 16: Winter: A-E } \\
\text { Summer: } 1-4\end{array}$ & --- & --- & --- & $\begin{array}{l}\text { Winter Climatic Severity Index, Summer Climatic } \\
\text { Severity Index } \\
\text { Data: simulations of buildings of various types }\end{array}$ \\
\hline $\begin{array}{l}\text { Morocco } \\
{[50]}\end{array}$ & 6 & --- & $\begin{array}{l}\text { HDD18 } \\
\text { CDD21 }\end{array}$ & --- & $\begin{array}{l}\text { Winter degree days and summer degree days } \\
\text { Simulations of annual heating and cooling requirements } \\
\text { used as a reference }\end{array}$ \\
\hline
\end{tabular}


Clustering analysis provides a possibility to consider multiple aspects of climate variables simultaneously (like different variables or seasonal difference of the same variables for time-serious data). It is further divided into two approaches, i.e. non-hierarchical (or flat) [59] and hierarchical techniques. An example of the former (K-means) assigns data into a pre-specified number of clusters or groups based on the distance between itself and a cluster centre point using a very efficient algorithm that may only find a local optimum [60]. Hierarchical clustering includes bottom-up (cumulative) and top-down (divisive) approaches. Hierarchical agglomerative clustering (HAC) methods have the advantage of not requiring pre-specification of the number of clusters and of being more repeatable than the highly variable flat method that returns a structured set of clusters [61-63]. However, the linkage criterion selection is critical as it determines how data are combined. Common, linkage criteria include single, complete, average, centroid, Ward's, V (vector), Graph degree. Ward's [64] and average linkage [65] are commonly used in climate analysis [61,62,66-68]. In the Ward's method, at each step the pair of clusters that leads to a minimum increase in withincluster variance is merged together, i.e. total within-cluster variance is minimized. There are some practices using clustering analysis to divide climates for building energy related issues. Wan et al. [51] applied clustering analysis with annual cumulative heat and cold stresses to get 9 clusters for China, and finally dividing 5 bioclimate zones after comparing their similarities. Lau et al. [52] split China into 5 prevailing solar climates using the Ward's method with monthly average daily clearness index. Walsh et al. compared three method, namely the degree-days division, the clustering analysis with climate variables and the administration divisions, for the climate zoning of Nicaragua [43], and proposed an new index the Mean Percentage of Misclassified Areas (MPMA) which shows zoning obtained using the cluster analysis and cooling degree-days may misclassify $18 \%$ areas, but $30 \%$ for the administrative divisions for their case [69].

\subsection{The Hot Summer and Cold Winter zone (HSCW), China}

The Hot Summer and Cold Winter zone in China is used to demonstrate the new method of climate zoning, as the 1.8 million $\mathrm{km}^{2}$ area (or $18.8 \%$ of China) (Figure 1) is home to 550 million 
179

180

people, accounts for 48\% of China's GDP (2010) [27]. During the period 1995 - 2004 [29] the monthly mean air temperatures $\left(T_{a v}\right)$ varied between 0 and $10^{\circ} \mathrm{C}$ (coldest month) and between 25 and $30^{\circ} \mathrm{C}$ (hottest month); with $T_{a v, d a y}<5{ }^{\circ} \mathrm{C}$ for less than 90 days per year and $T_{a v, d a y}>25{ }^{\circ} \mathrm{C}$ for 40 to 110 days per year. However given the historical lack of central heating systems, the indoor conditions in winter are colder than both the Cold and Severe Cold zones [70,71].

The HSCW zone is a transition region with HDD18 (heating degree day based on $18{ }^{\circ} \mathrm{C}$ ) varying from 700 to $2000{ }^{\circ} \mathrm{C}$. As this wide range is not helpful for climate-responsive passive design strategies, the MOHURD revised national standard (GB 50176-2016 Code for Thermal Design of Civil Building), sub-divides the zone using HDD18 thresholds (Figure 1b) into 3A (1200 - $\left.2000{ }^{\circ} \mathrm{C}\right)$ and $3 \mathrm{~B}\left(700-1200{ }^{\circ} \mathrm{C}\right)$. This is driven by heating demands and building insulation design guidance. As cooling demands, humidity, solar exposure and wind resources are not comprehensively considered it does not provide much practical help to overall climate-responsive passive design [11]. For example, designers would like to know if the wind and outdoor air temperature could enhance natural ventilation and how to balance solar photo-thermal utilization and shading.

\section{Methods}

This research aims to develop a rigorous method of generating finer climate zones for the purpose of building energy design. The Hot Summer and Cold Winter zone of China is used to demonstrate the method, but it could be applied in any region. Figure 2 provides an overview of methods used to subdivide an area. 


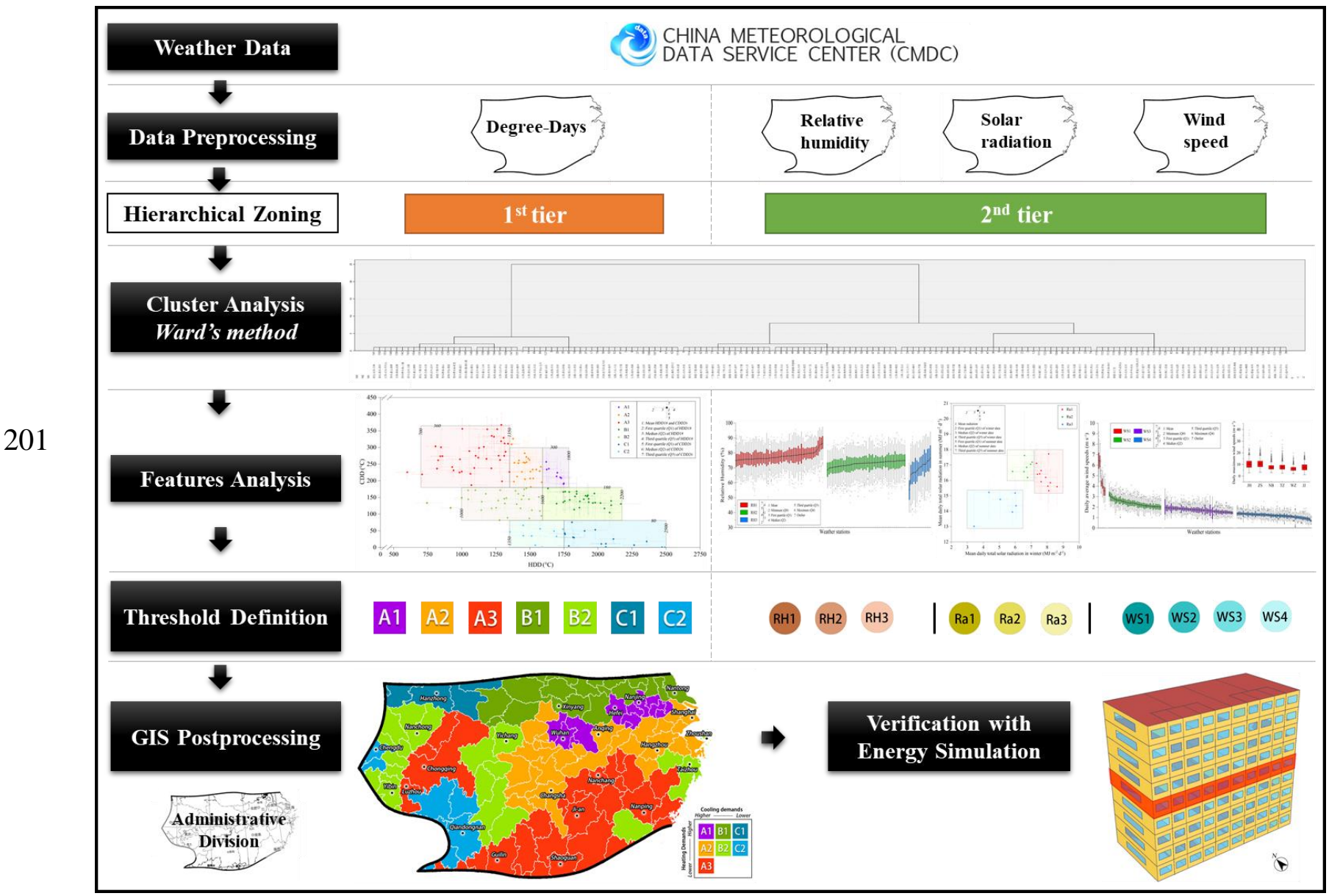

Figure 2: Overview of the climatic zoning method

\subsection{Data collection and pre-processing}

As climate variations impact energy use in the built environment [72,73] and this region

(middle and lower reaches of the Yangtze River) has experienced increasing temperature for most cities $\left(0.3-0.4^{\circ} \mathrm{C}[10 \mathrm{y}]^{-1}\right)[74]$, the heating and cooling demands of buildings $[58,75]$ for the period 2006-2015 are analysed.

Daily observations from China Meteorological Administration (http://data.cma.cn/) [76,77] weather stations within, and on, the HSCW zone boundary (as defined in the Standard GB 501762016 [29]) are analysed after excluding stations with large amounts of missing data (>5\%) and/or high elevation stations (> $1200 \mathrm{~m}$ ) (Table 2). The stations used are gap-filled by interpolating between the two adjacent time periods. The number of stations with missing data is: $16 \%$ for wind, 

missing days in the 10-year period: 14 (48), 1 (3) and 2 (7), respectively.

Table 2: Characteristics of the measurements from state weather stations [78] with the number of stations (N) used

\begin{tabular}{|l|l|l|l|l|l|l|}
\hline \multicolumn{2}{|l|}{ Variable } & Height $(\mathbf{m})$ & Range & Resolution & Accuracy & N \\
\hline Temperature & Daily mean/maximum/minimum & $1.50 \pm 0.05$ & $-50-50{ }^{\circ} \mathrm{C}$ & $0.1^{\circ} \mathrm{C}$ & $\pm 0.2^{\circ} \mathrm{C}$ & 160 \\
\hline $\begin{array}{l}\text { Relative } \\
\text { Humidity }\end{array}$ & Daily mean/minimum & $1.50 \pm 0.05$ & $0-100 \%$ & $1 \%$ & $\begin{array}{l} \pm 4 \%(\leq 80 \%) \\
\pm 8 \%(>80 \%)\end{array}$ \\
\hline \multirow{2}{*}{ Radiation } & Daily sunshine hours & --- & $0-24 \mathrm{~h}$ & $60 \mathrm{~s}$ & $\pm 0.1 \mathrm{~h}$ & 122 \\
\cline { 2 - 7 } & Daily total solar radiation & $1.50 \pm 0.10$ & $0-2000 \mathrm{~W} \mathrm{~m}^{-2}$ & $1 \mathrm{~W} \mathrm{~m}^{-2}$ & $\pm 5 \%$ & 24 \\
\hline \multirow{2}{*}{ Wind } & Daily mean/maximum wind speed & $10-12$ & $0-60 \mathrm{~m} \mathrm{~s}^{-1}$ & $0.1 \mathrm{~m} \mathrm{~s}^{-1}$ & $\begin{array}{l} \pm\left(0.5 \mathrm{~m} \mathrm{~s}^{-1}+0.03 v\right) \\
v: \text { wind speed }\left(\mathrm{m} \mathrm{s}^{-1}\right)\end{array}$ \\
\cline { 2 - 7 } & Direction of maximum & $10-12$ & $0-360^{\circ}$ & $3^{\circ}$ & $\pm 5^{\circ}$ \\
\hline
\end{tabular}

Degree-day measures how much warmer or cooler than a base temperature a period is. Here CDD and HDD are the principal indices used. They are calculated for clustering inputs with base temperatures of $26{ }^{\circ} \mathrm{C}$ for $\mathrm{CDD}\left(T_{B, C}\right)$ and $18{ }^{\circ} \mathrm{C}$ for $\operatorname{HDD}\left(T_{B, H}\right)$ from the daily average temperature $\left(T_{i},{ }^{\circ} \mathrm{C}\right)[29]$ :

to analyse the differences in the variables' magnitude and the seasonal variations among selected

\subsection{Hierarchical agglomerative clustering}

These data are analysed with hierarchical agglomerative clustering (HAC). Initially, each station is treated as a separate cluster. These are successively merged using some dissimilarity between each cluster until the criteria (variance size) to stop merging is reached.

To measure the dissimilarity of each variable between any two stations, the squared Euclidean distance of a variable between station $i$ and $j\left(d_{i j}\right)$ is determined:

$$
d_{i j}=\sum_{t=1}^{m}\left(v_{i_{t}}-v_{j_{t}}\right)^{2}
$$


where $t$ is the time sequence of each value in a variable dataset of length $m$, and $v_{i t}$ and $v_{j t}$ are the $t^{\text {th }}$ data for station $i$ and station $j$ respectively.

In this research, we use the Ward's method for clustering. At each agglomerative step, two clusters with minimum dissimilarity measures are grouped together, then all the dissimilarity measures are updated for the currently available cluster:

$$
d_{(i j) k}=\frac{n_{i}+n_{k}}{n_{i}+n_{j}+n_{k}} d_{i k}+\frac{n_{j}+n_{k}}{n_{i}+n_{j}+n_{k}} d_{j k}-\frac{n_{k}}{n_{i}+n_{j}+n_{k}} d_{i j}
$$

where $d_{(i j) k}$ is the squared Euclidean distance between the new cluster $(i j)$ and any other cluster $k ; d_{i j}$, $d_{i k}$ and $d_{j k}$ are the squared Euclidean distances between clusters as indicated by two subscripts; and $n_{i}, n_{j}$ and $n_{k}$ are the number of stations in each cluster.

These results are typically shown in a dendrogram ("Clustering Analysis - Ward's method" in Figure 2).

\subsection{Analysis and threshold definition}

The first tier (Figure 2) of clusters are developed from annual HDD18 and CDD26 data normalized by their respective maxima. The threshold for merging clusters is determined from analysis of the stations HDD18 and CDD26 inter-quartile ranges (IQR, i.e. 75 - 25 percentile). The final map is modified to ensure spatial consistency.

In the second tier, the remaining variables (Table 2) are used. For relative humidity, high and low variance areas were identified. The low variance group is sub-divided into extremely high and high humidity. HAC analyses of monthly averages of both daily total solar radiation and wind speed provide two sets of clusters. The seasonal characteristics (especially in summer and winter) of radiation and the magnitudes of the wind speed were evaluated, as references for the specific dividing thresholds.

\subsection{Verification by energy consumption simulation}


To assess the new climate zones, simulations of indoor environment and energy consumption are performed using EnergyPlus (version 8.4.0, [79]). EnergyPlus is based on the energy balance for the zone air which considers: I convective internal loads; II convective heat transfer from the zone surfaces, III heat transfer from inter-zone air mixing, IV heat transfer from infiltration of outside air, and $\mathrm{V}$ the output from mechanical systems providing hot or cold air to the zones to meet heating or cooling loads [79]:

$$
C_{z} \frac{d T_{z}}{d t}=\sum_{i=1}^{N_{s l}} \dot{Q}_{i}+\sum_{i=1}^{N_{\text {surfaces }}} h_{i} A_{i}\left(T_{s i}-T_{z}\right)+\sum_{i=1}^{N_{\text {zones }}} \dot{m}_{i} C_{p}\left(T_{z i}-T_{z}\right)+\dot{m}_{\text {inf }} C_{p}\left(T_{\infty}-T_{z}\right)+\dot{Q}_{s y s}
$$

II

III

IV

where $C_{z} \frac{d T_{z}}{d t}$ is the energy stored in zone air. For more details of the model see [74].

The heating and cooling energy consumptions are simulated for a standard Chinese residential building (Figure 3a) with those construction parameters and occupant's schedule (Table 3) with weather conditions from representative cities in the different zones. The middle floor of a very common Chinese megacity medium-rise apartment block [37] (Figure 3a), with a north-south orientation of the main facades, is simulated. The floor plan (Figure 3b) has four apartments (306 $\mathrm{m}^{2}$ ) and two stairwells (total $72 \mathrm{~m}^{2}$ ). Three thermal zones are modelled: the four apartments as a single zone and the stairwells as two separate zones. different climates and the impact on passive technologies selection, rather than design optimization.

These simulations are used to assess the thermal characteristics of this standard building under The calculated annual heating/cooling loads are used to access the winter/summer results, and freerunning periods [37] are used in spring and autumn.

Table 3: Parameters used in the EnergyPlus simulations are all from [37] (originally refer to the Chinese standard [27])

\begin{tabular}{|c|c|c|c|}
\hline \multicolumn{4}{|l|}{ Parameters } \\
\hline U-value $\left(\mathrm{W} \mathrm{m}^{-2} \mathrm{~K}^{-1}\right)$ & External wall $=0.804$ & \multicolumn{2}{|c|}{$\begin{array}{l}\text { External window }=2.667 \\
(6 \mathrm{~mm} \text { coated glazing }+12 \mathrm{~mm} \text { air }+6 \mathrm{~mm} \text { clear glazing })\end{array}$} \\
\hline Window to Wall ratio & North $=0.3$ & South $=0.4$ & East $=$ West $=0.2$ \\
\hline Air exchange rate $\left(\mathrm{h}^{-1}\right)$ & \multirow{2}{*}{\multicolumn{3}{|c|}{\begin{tabular}{l|l} 
Infiltration $=1$ & Ventilation $=5$ \\
0.03 (Activity: sit, heat emission rate: $125.60 \mathrm{~W}_{\text {person }}{ }^{-1}$ ) (All day occupied)
\end{tabular}}} \\
\hline Occupant density $\left(\mathrm{m}^{-2}\right)$ & & & \\
\hline Energy consumption index $\left(\mathrm{W} \mathrm{m}^{-2}\right)$ & \multicolumn{3}{|c|}{\begin{tabular}{|l|l} 
Lighting $=6.0$ & Equipment $=4.3$ \\
\end{tabular}} \\
\hline Thermal comfort range $\left({ }^{\circ} \mathrm{C}\right)$ & \multicolumn{3}{|l|}{$18-26$} \\
\hline
\end{tabular}




\begin{tabular}{|l|l|}
\hline Parameters & \\
\hline Cooling/Heating mode & Continuously operating when indoor temperature is beyond the thermal comfort range \\
\hline
\end{tabular}
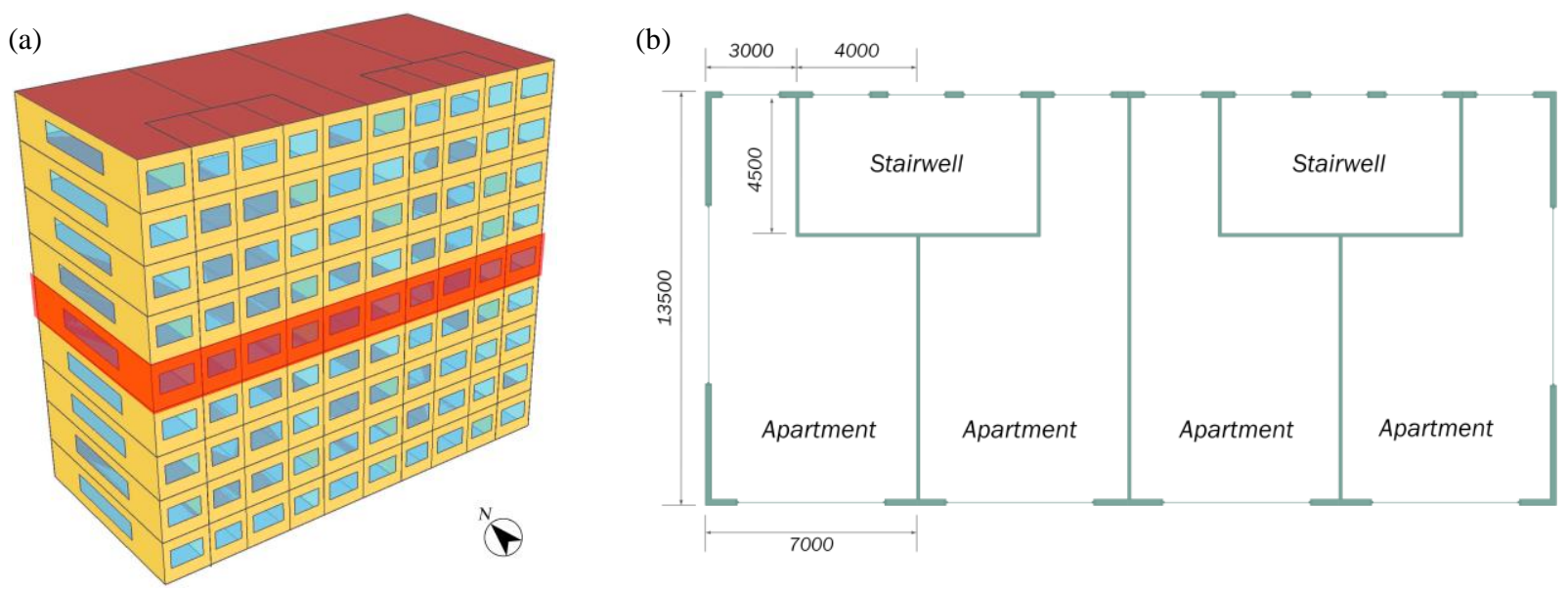

Figure 3: EnergyPlus simulations of (a) one floor (red) with (b) floor plan (units: mm, the height of this floor: 2.8 $\mathrm{m})$

\section{Results and discussion}

\subsection{Subdivision based on Degree-days}

Using the methods described in section 2, the HSCW zone is sub-divided into seven (Figure 4). From the CDD26 data three areas with decreasing cooling demands are identified: A (high), B (medium), C (low). These are sub-divided by heating demands, namely A1, A2, A3, B1, B2, C1 and C2 (1 for high, 2 for medium and 3 for low). As some stations are on/near the dividing lines (Figure $4 a)$, it is necessary to decide which class they should belong to. Given temporal variations in temperature may cause some stations to change sub-zone, spatial continuity (Figure 4b) is used to finalize the selection.

Within the HSCW zone, the southeast is obviously warmer than the northwest. The hottest subzone A3 (Figure 4), with the largest cooling demands and lower heating demands, is located along the southern boundary of the HSCW zone (Jiangxi, south of Hunan, north of Fujian, and northern part of Guangdong and Guangxi) adjacent to the Hot Summer and Warm Winter (HSWW) zone; and, in the Sichuan Basin area where mountains surround cities such as Chongqing where air 
temperatures can reach $42^{\circ} \mathrm{C}$ [76]. A1 and A2 with the same cooling but larger heating demands (A1 still larger than A2) is in the middle-east of the HSCW zone, downstream of the Yangtze River. It includes metropolises like Shanghai, Hangzhou, Nanjing, Wuhan, and Changsha. With less cooling needs B1, B2, C1 and C2 are in the north and west of the HSCW zone, adjacent to the Severe Cold (SC), Cold (C) and Temperate (T) zones. B1 with large heating demands is to the north. B2 is split into three: two areas in the west separated by the Chongqing (A2); and, one area on the East China Sea coast. This area has cooler heatwaves than the surrounding A2 but similar heating requirements. $\mathrm{C} 1$ has higher heating than $\mathrm{C} 2$, and they have the lowest cooling needs as it is close to the SC and $\mathrm{T}$ zones.

In general, for the HSCW zone: 1) lower latitudes have more cooling demands than higher latitudes; 2) coastal areas have more cooling needs than inland areas.

(a)

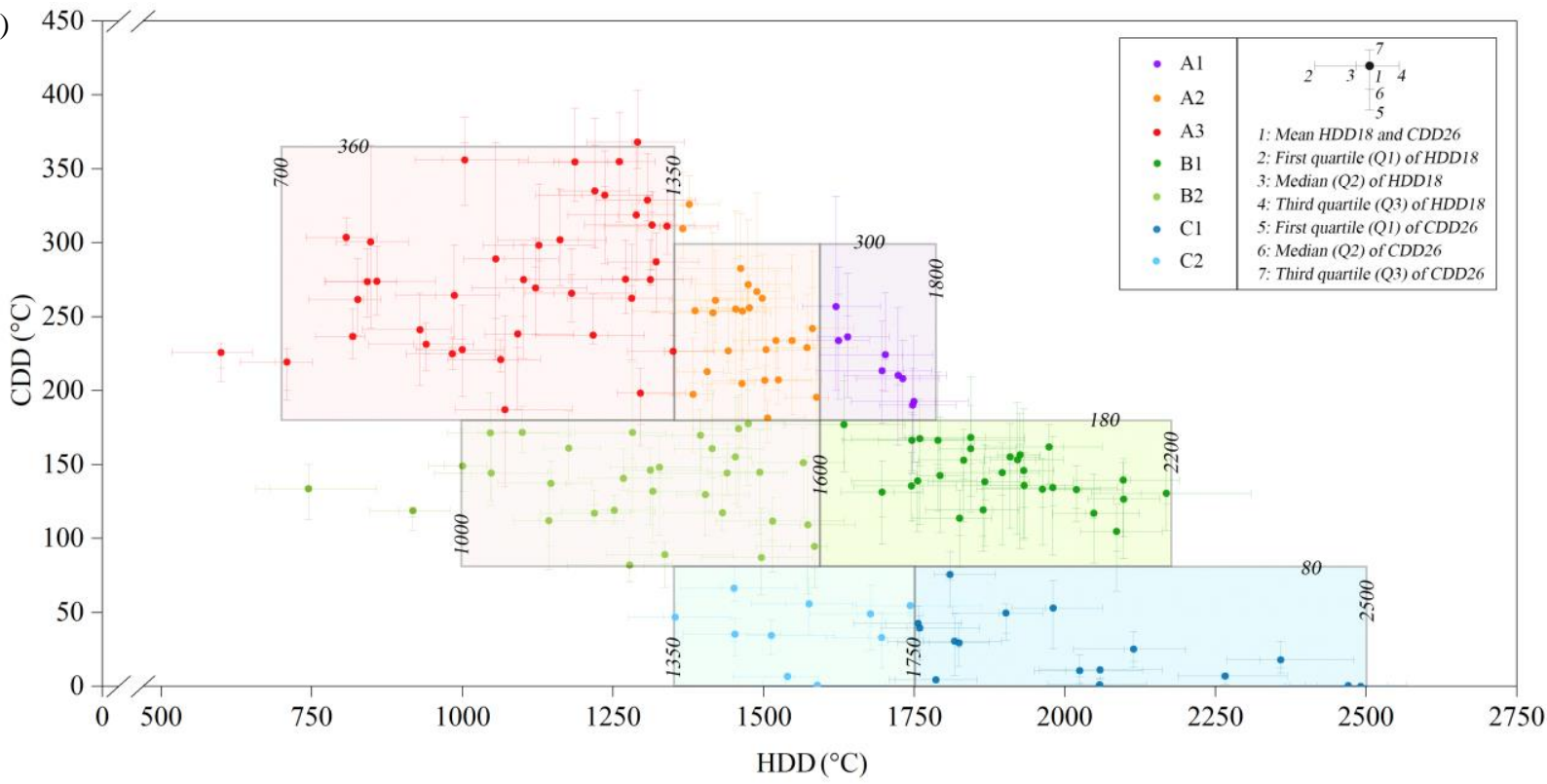




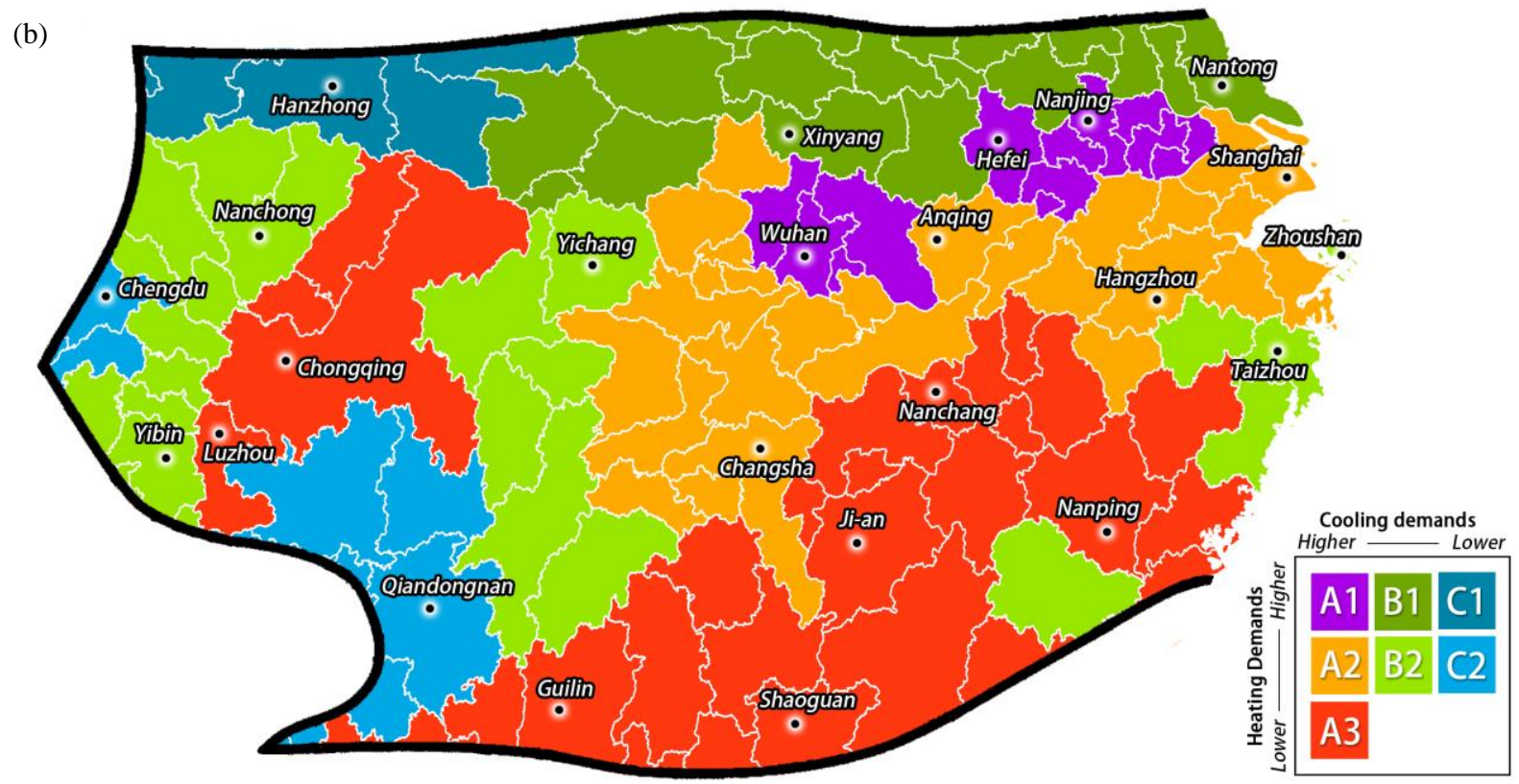

Figure 4: Sub-zones identified using HDD18 and CDD26 (a) mean and quartiles for each observation station with dividing thresholds and (b) map with city administrative boundaries (white).

\subsection{Second tier zones}

Relative humidity is generally high in the HSCW zone, with annual means in most cities of $65 \%$ to $85 \%$, and minimum monthly averages above $40 \%$ (Figure 5). Given this HVAC energy is used for dehumidification to secure occupants' comfort. Outdoor temperature and humidity influence the natural ventilation potential in spring and autumn.

The HSCW zone is sub-divided into three relative humidity classes. The three groups differ in terms of their variability, with the IQR greatest in RH3 (13.5\%) and smaller in RH2 (8.8\%) and RH1 $8.2 \%$ ). Overall, the mean is larger in RH1 (annual mean $>75 \%$, minimum monthly average > $60 \%$ ) than RH2 (annual mean 68 to 75\%) and lowest in RH3. Thus, RH1 and RH2 areas experience uncomfortable or unhealthy (normally $<60 \%$ for indoor environments [80]) conditions whereas RH3 areas will be variable but dry compared to the rest of the HSCW zone. 


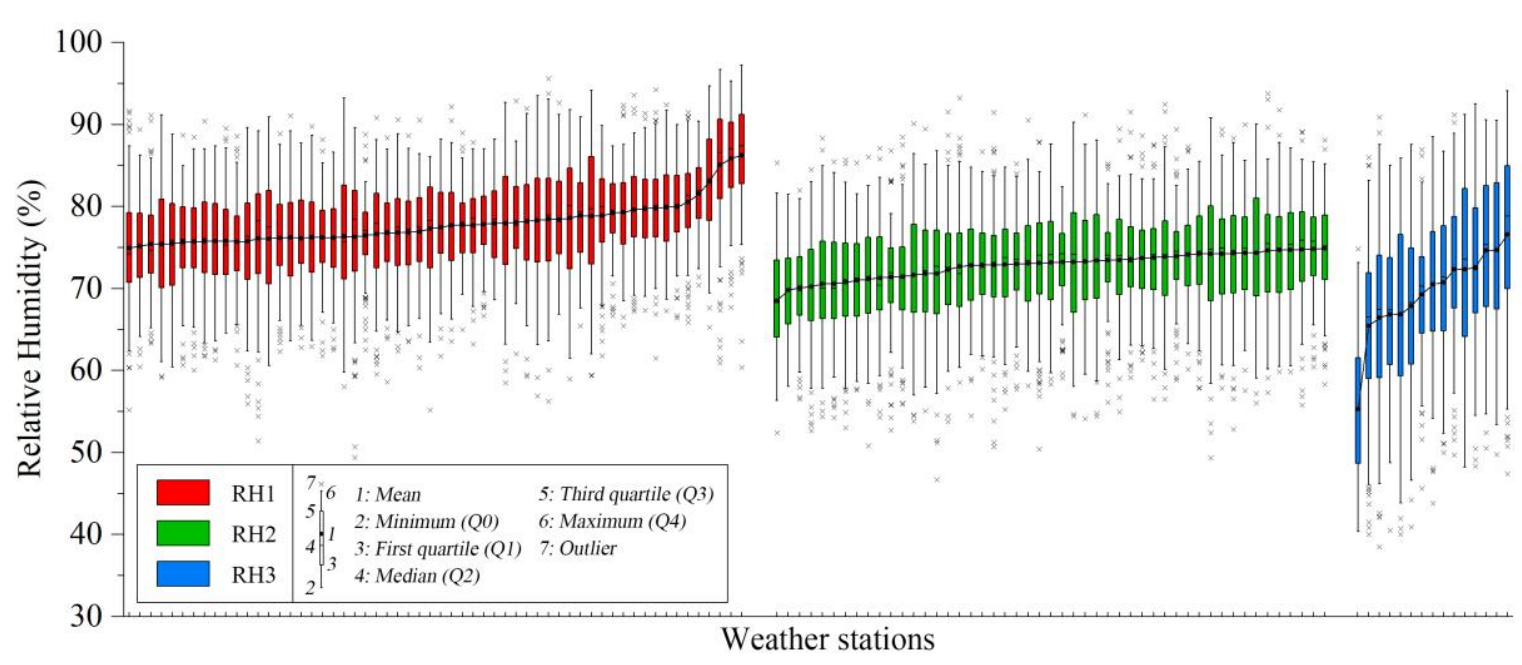

Figure 5: Three relative humidity classes (colour) with mean, median and IQR for each station (outlier: $>1.5$ IQR).

In winter, direct solar heat gain can improve occupants' thermal comfort and reduce heating demands. However, in summer it can increase the cooling load. HAC analysis of summer and winter daily totals creates three radiation ( $\mathrm{Ra}$ ) clusters (Figure 6): Ra1 - high all year round (summer $>15$, winter $>7 \mathrm{MJ} \cdot \mathrm{m}^{-2} \mathrm{~d}^{-1}$ ); Ra2 - high in summer but lower in winter than Ra1; and Ra3 - more limited solar radiation all year round (e.g. summer: 13.02 ; winter: $3.42 \mathrm{MJ} \cdot \mathrm{m}^{-2} \mathrm{~d}^{-1}$ for the lowest city). Ra3 includes the Sichuan Basin (Chongqing, Chengdu, Luzhou and Mianyang) which is consistent with Lau et al.'s five solar zones for China where the Sichuan Basin is a distinct zone [52]. Solar radiation helps solar space heating and domestic hot water production using solar photothermal systems [25], and electricity generation using solar photo-electricity [81]. Although applicable for Ra1 and Ra2, there is much less resource in Ra3. 


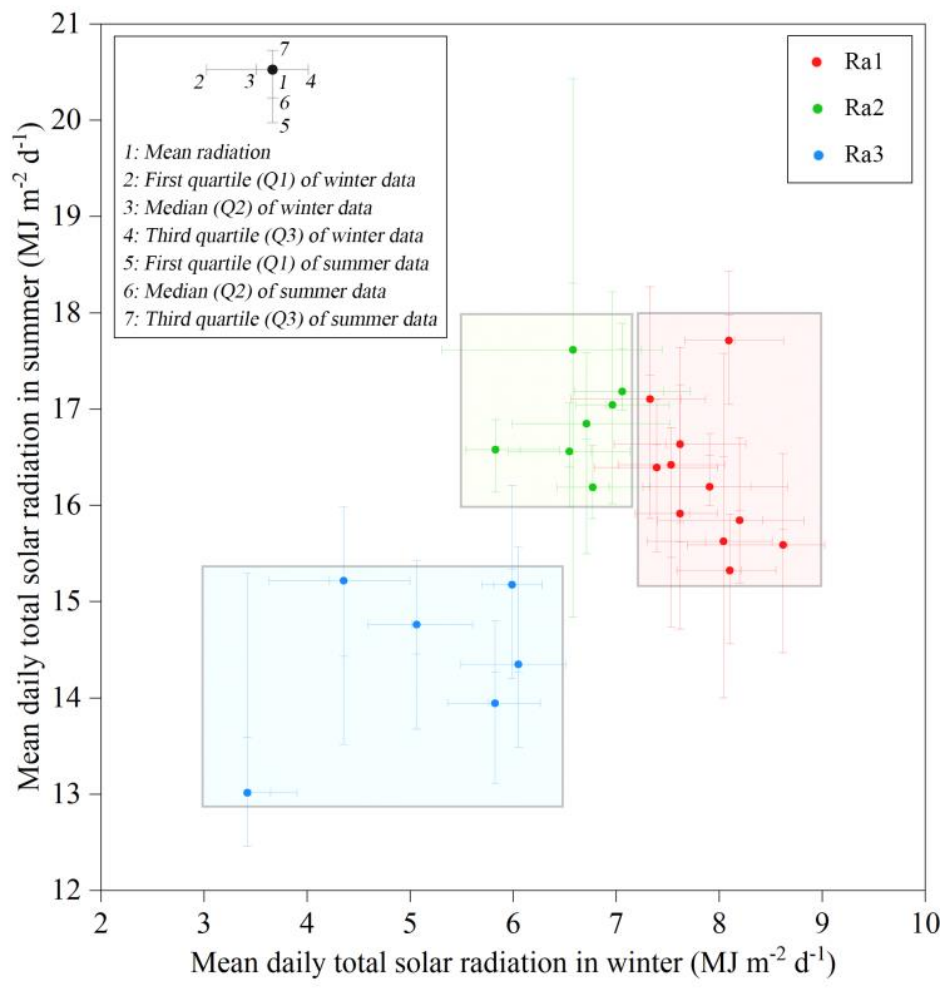

Figure 6: Three solar radiation classes (colour) derived from HAC analysis of daily total solar radiation in winter (DJF) and summer (JJA) with each station (mean and quartiles).

HAC analysis of monthly average wind speeds sub-divided the HSCW into four clusters (Figure 7) with decreasing mean values: WS1 $\left(\geq 3.5 \mathrm{~m} \mathrm{~s}^{-1}\right)$, WS2 $\left(2.0 \leq \mathrm{WS}<3.5 \mathrm{~m} \mathrm{~s}^{-1}\right)$, WS3 $(1.5$ $\left.\leq \mathrm{WS}<2.0 \mathrm{~m} \mathrm{~s}^{-1}\right)$ and WS4 $\left(<1.5 \mathrm{~m} \mathrm{~s}^{-1}\right)$. Higher wind speeds can provide more natural ventilation, but also induce draughts. Typically, weather stations are in more open places than building sites so the latter will likely experience much lower wind speeds (e.g. Kent et al. [82]). The highest wind speeds (WS1) are on the Zhejiang coast an area which experiences tropical depression and typhoons. Wenzhou has had at least 75 days with daily maximum $\geq 10.8 \mathrm{~m} \mathrm{~s}^{-1}$ (lower threshold of tropical depression) in the 10-year period (Figure 7). WS2 covers the Yangtze Plain (middle-lower reaches of the Yangtze River, near the coast) and a few inland cities; this region has great potential for natural ventilation. Most of the inland cities in the HSCW zone are classified as WS3 and WS4. WS3 contains a lot of hilly areas and plateaus, causing higher wind speeds than WS4 are more sheltered areas. 


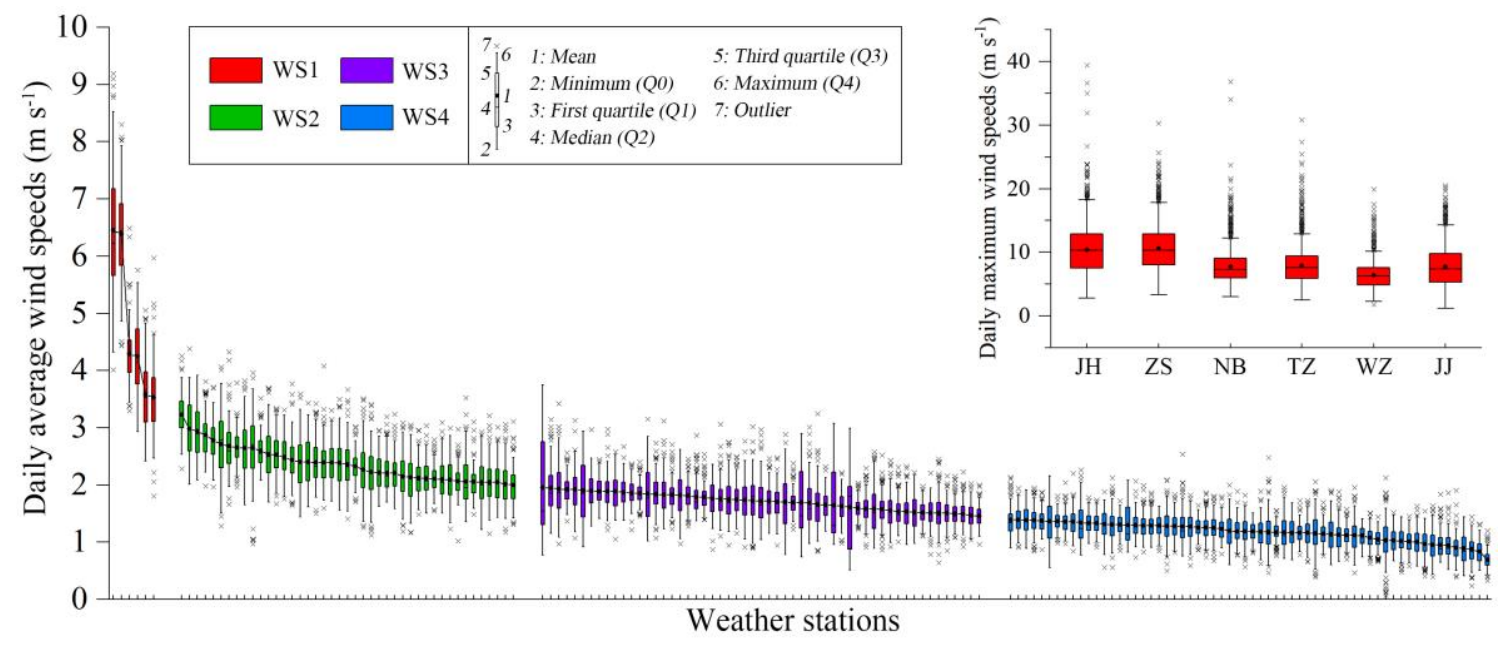

Figure 7: As Figure 5, but for the four wind classes (colour). The six WS1 cities are left to right: Jinghua (JH), Zhoushan (ZS), Ningbo (NB), Taizhou (TZ), Wenzhou (WZ) and Jiujiang (JJ).

For the full results of sub-zone divisions see Appendix Table A.1.

\subsection{Energy simulations for new sub-zones}

The impact of the proposed climate sub-zones is assessed using simulations of indoor thermal environment and energy consumption (Section 2.4) for 17 cities that experience the range both first and second tier conditions (Table 4, Figure 4b).

The simulated cooling loads (Table 4, Figure 8) decreased from sub-zone A (mean $82.8 \mathrm{kWh}$ $\mathrm{m}^{-2}$ ) to $\mathrm{B}$ (mean $65.3 \mathrm{kWh} \mathrm{m}^{-2}$ ) to $\mathrm{C}$ (mean $43.8 \mathrm{kWh} \mathrm{m}^{-2}$ ). The differences in means are assessed using the two independent samples (or two sample Student's) T Test [83]. Between zone A and B, there is a statistically significant difference at an alpha level $(\alpha)$ of $0.05(\mathrm{~T}=3.741$, $\mathrm{df}=12$, sig.(2tailed $)=0.003<\alpha)$; and between $\mathrm{B}$ and $\mathrm{C}(\mathrm{T}=5.863, \mathrm{df}=6$, sig. $(2$-tailed $)=0.001<\alpha)$. The variance within the larger geographical area sub-zone $\mathrm{A}(\mathrm{n}=9$, standard deviation $(\mathrm{sd})=11.6 \mathrm{kWh}$ $\left.\mathrm{m}^{-2}, \mathrm{IQR}=21.9 \mathrm{kWh} \mathrm{m}^{-2}\right)$ is larger than $\mathrm{B}\left(\mathrm{n}=5, \mathrm{sd}=5.8 \mathrm{kWh} \mathrm{m}^{-2}, \mathrm{IQR}=9.9 \mathrm{kWh} \mathrm{m}^{-2}\right)$ and $\mathrm{C}(\mathrm{n}=$ $3, \mathrm{sd}=2.9 \mathrm{kWh} \mathrm{m}^{-2}, \mathrm{IQR}=2.7 \mathrm{kWh} \mathrm{m}^{-2}$ ).

The average required heating loads of sub-zone A1 is larger than A2 and A3 (cf. 39 to 28 to 13 $\mathrm{kWh} \mathrm{m}^{-2}$ ), B1 greater than B2 (cf. 41 to $20 \mathrm{kWh} \mathrm{m}^{-2}$ ), and $\mathrm{C} 1$ greater than $\mathrm{C} 2$ (44 to $26 \mathrm{kWh} \mathrm{m}^{-2}$ ) 
(Table 4, Figure 8). Given the small sample sizes ( $\mathrm{n}=1$ for $\mathrm{C} 1$ ) no statistical evaluation of difference

Table 4: EnergyPlus simulation (Table 3, Figure 3) results for a typical residential building under different local weather conditions for 16 representative cities (* missing data required nearest site result assigned).

\begin{tabular}{|c|c|c|c|c|c|c|c|c|c|}
\hline $\begin{array}{l}\text { Sub- } \\
\text { zone }\end{array}$ & Province & City & Humidity & Radiation & Wind & $\begin{array}{c}\text { Cooling } \\
\text { Load } \\
\left(\mathrm{kWh} \mathrm{m}^{-2}\right)\end{array}$ & $\begin{array}{c}\text { Heating } \\
\text { Load } \\
\left(\mathrm{kWh} \mathrm{m}^{-2}\right)\end{array}$ & $\begin{array}{l}\text { Non-heating } \\
\text { and cooling } \\
\text { period } \\
\text { (h) }\end{array}$ & $\begin{array}{l}\text { Mean } \pm \\
\text { s.d. } \\
\text { cooling } \\
\text { load }\end{array}$ \\
\hline \multirow{3}{*}{ A1 } & Hubei & Wuhan & $\mathrm{RH} 1$ & $\mathrm{Ra} 2$ & wS3 & 95.5 & 32.0 & 3044 & \multirow[t]{9}{*}{$82.8 \pm 11.6$} \\
\hline & Anhui & Hefei & $\mathrm{RH}^{*}$ & Ra1 & wS2 & 75.6 & 43.3 & 3192 & \\
\hline & Jiangsu & Nanjing & $\mathrm{RH}^{2}$ & Ra1 & wS2 & 73.1 & 43.0 & 3557 & \\
\hline \multirow{3}{*}{ A2 } & Hunan & Changsha & $\mathrm{RH} 2$ & $\mathrm{Ra} 2$ & wS2 & 81.5 & 28.2 & 3271 & \\
\hline & Zhejiang & Hangzhou & $\mathrm{RH} 2$ & Ra1 & wS2 & 73.6 & 28.8 & 3592 & \\
\hline & Shanghai & Shanghai & $\mathrm{RH} 2$ & Ra1 & wS2 & 68.9 & 27.0 & 4067 & \\
\hline \multirow{3}{*}{ A3 } & Fujian & Nanping & RH1 & Ra1 & WS4 & 100.0 & 5.7 & 5437 & \\
\hline & Jiangxi & Ji-an & RH1 & $\mathrm{Ra}^{*}$ & wS3 & 96.7 & 18.8 & 4869 & \\
\hline & Chongqing & Chongqing & RH1 & Ra3 & WS4 & 79.9 & 12.9 & 3808 & \\
\hline & Henan & Xinyang & $\mathrm{RH} 2$ & Ra1 & wS2 & 61.9 & 46.1 & 4779 & \multirow[t]{5}{*}{$65.3 \pm 5.8$} \\
\hline & Jiangsu & Nantong & RH1 & Ra1 & wS2 & 60.1 & 35.9 & 5106 & \\
\hline \multirow{3}{*}{ B2 } & Hubei & Yichang & $\mathrm{RH} 2$ & Ra3 & WS4 & 72.0 & 30.7 & 3354 & \\
\hline & Zhejiang & Zhoushan & $\mathrm{RH} 1$ & Ra1" & WS1 & 71.2 & 20.6 & 5475 & \\
\hline & Sichuan & Yibin & RH1 & Ra3* & WS4 & 61.3 & 9.1 & 4248 & \\
\hline C1 & Shanxi & Hanzhong & $\mathrm{RH} 1$ & $\mathrm{Ra}^{*}$ & WS4 & 42.7 & 43.6 & 4833 & \multirow[t]{3}{*}{$43.8 \pm 2.9$} \\
\hline \multirow{2}{*}{$\mathrm{C} 2$} & Sichuan & Chengdu & $\mathrm{RH} 1$ & Ra3 & WS4 & 47.1 & 22.0 & 4462 & \\
\hline & Guizhou & Qiandongnan & RH1) & $\mathrm{Ra}^{*}$ & wS3 & 41.7 & 30.8 & 5237 & \\
\hline
\end{tabular}



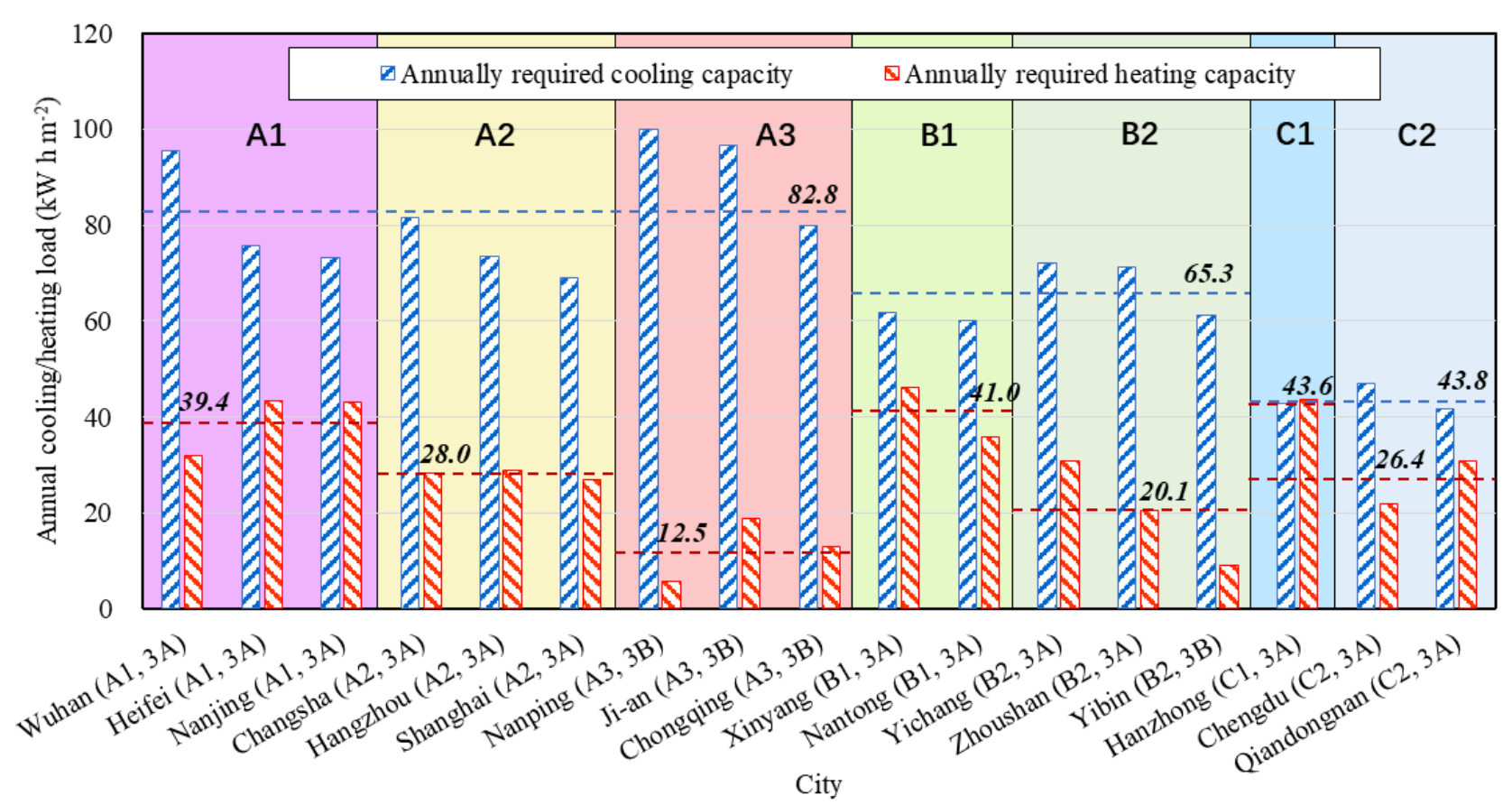

Figure 8: Simulated annual cooling and heating loads for a typical building (Figure 3) in 17 representative cities

(Figure 4, Table 4) from new 7 sub-zones (A1, A2, A3, B1, B2, C1 and C2) and current standard divisions ( $3 \mathrm{~A}$ and $3 \mathrm{~B}$ ), and the average for each new sub-zone (indicated above the dash line: blue one shows the average of cooling load for group A, B and C; red one shows the average of heating load for all sub-zones).

Comparing the divisions in current standard [29], among those typical cities, all of three cities in $\mathrm{A} 3$ and one city in $\mathrm{B} 2$ belongs to $3 \mathrm{~B}$, and all remaining cities belongs to $3 \mathrm{~A}$. For cooling loads, $3 \mathrm{~A}$ is averaged to be $66.5 \mathrm{kWh} \mathrm{m}^{-2}$ with $\mathrm{sd}=15.6 \mathrm{kWh} \mathrm{m}^{-2}$, and $3 \mathrm{~B}$ is averaged to be $84.5 \mathrm{kWh} \mathrm{m}^{-2}$ with $\mathrm{sd}=17.8 \mathrm{kWh} \mathrm{m}^{-2}$. The discrepancy is not obvious for only two groups available, and their standard deviations within group are higher than new sub-divisions.

The heating load for Nanping is lower than the other A3 cities (Figure 8) as it receives large amounts of solar radiation all the year round (i.e. Ra1). With means of $8.09 \mathrm{MJ} \mathrm{m}^{-2} \mathrm{~d}^{-1}$ in winter and 17.72 $\mathrm{MJ} \mathrm{m}^{-2} \mathrm{~d}^{-1}$ in summer, these are amongst the highest in this region. As indicated, the external heat gains from solar radiation can significantly reduce the need for additional heating.

The free-running period (FRP) when neither heating nor cooling is required (i.e. in spring and autumn) can be extended with appropriate shading and natural ventilation [37]. As higher wind speeds can enhance natural ventilation in transition seasons, the relations between the length of this period and wind sub-zones (stratified by temperature zone) are analysed (Figure 9). Areas with 
higher wind speeds tend to have the longer simulated FRP: for A1 $\mathrm{FRP}_{\mathrm{WS} 2}>\mathrm{FRP}_{\mathrm{WS} 3}$; for $\mathrm{B} 2$ $\mathrm{FRP}_{\mathrm{WS} 1}>\mathrm{FRP}_{\mathrm{WS} 4}$; and $\mathrm{C} 2, \mathrm{FRP}_{\mathrm{WS} 3}>\mathrm{FRP}_{\mathrm{WS} 4}$. However, as expected $\mathrm{A} 3$ does not follow this

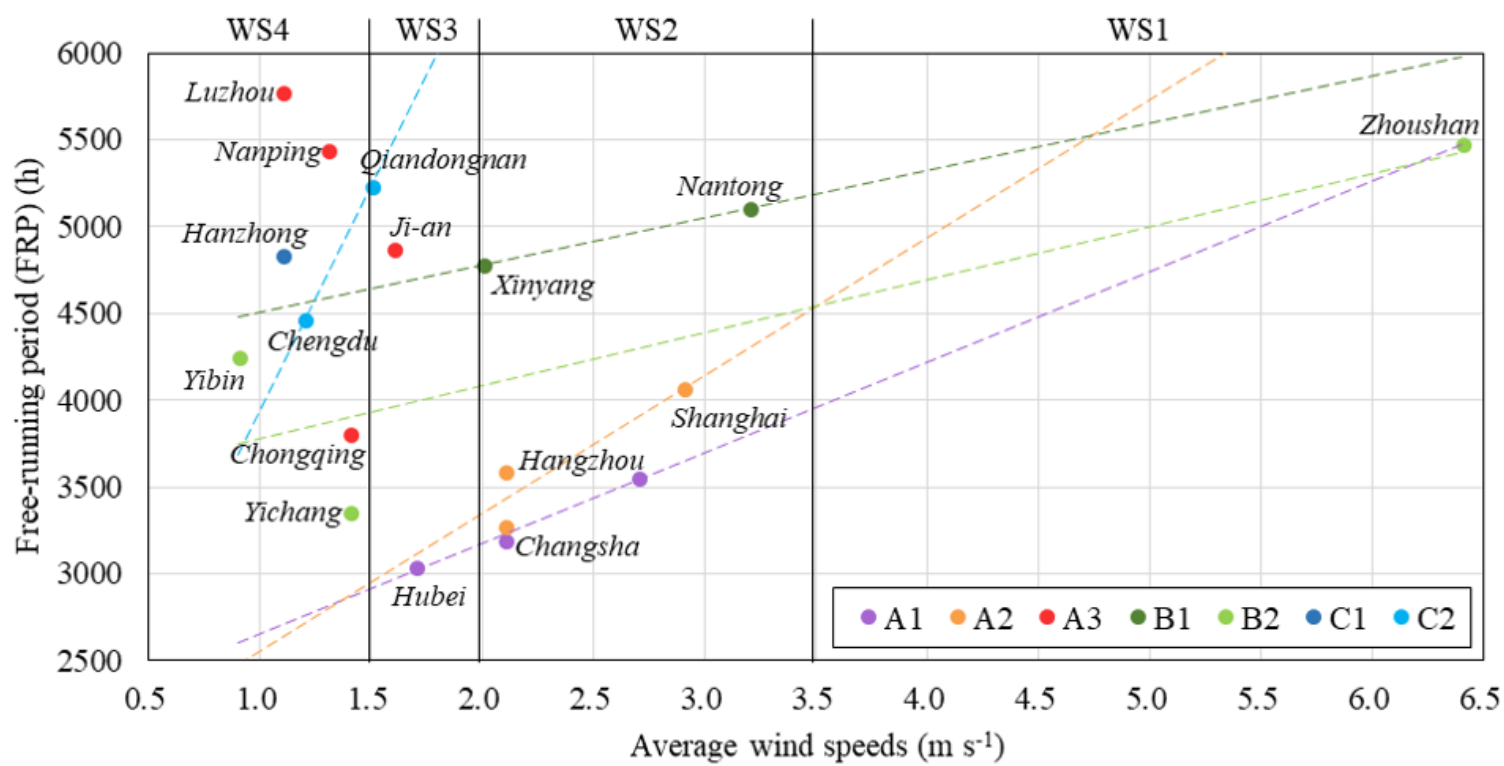

Figure 9: The relation between average wind speed and simulated length of a period not needing heating or cooling (h), comparison among wind classes (Figure 7) for cities (dots) in thermal sub-zones (A1, A2, A3, $\mathrm{B} 1, \mathrm{~B} 2, \mathrm{C} 1, \mathrm{C} 2$ ). The tendency (dashed lines) follows that the larger wind speed contributes to the longer free-running period for $\mathrm{A} 1, \mathrm{~A} 2, \mathrm{~B} 1, \mathrm{~B} 2$ and $\mathrm{C} 2$.

\section{Conclusions}

A new method to obtain zones for climate-responsive building design for heating and cooling based on hierarchical agglomerative clustering (HAC) with a technique to generalise threshold criteria is presented. The method is demonstrated for the Chinese Hot Summer and Cold Winter zone, which is regarded as a challenging region for low-carbon heating and cooling solutions given its diverse climate. The impact of climate zoning on energy consumption is demonstrated by simulating (EnergyPlus) heating and cooling loads for a typical residential building in different subzones. The cooling demands across sub-zones (A, B and C) are significantly different with mean heating demands also different $(\mathrm{A} 1>\mathrm{A} 2>\mathrm{A} 3$; $\mathrm{B} 1>\mathrm{B} 2$; $\mathrm{C} 1>\mathrm{C} 2)$. Areas with higher wind speeds 
can potentially have longer free-running periods.

The main conclusions from this study are:

- The two-tier method of climate zoning based on first HDD and CDD, and secondly relative humidity, solar radiation and wind speed provides more consistent climate subzones. These will enhance the implementation of the improved climate-responsive passive design in practice. The method will help the identification of key climatic factors that will affect the building energy design and the utilisation of natural resources.

- The current standard with two sub-zones for the Hot Summer and Cold Winter zone does not properly identify the diverse climates in this region, so would likely result in the poorer energy efficiency of building designs. Sub-division into seven, based on heating and cooling, improves the spatial resolution of heating/cooling loads. These are demonstrated (by simulation) to have different building energy demands. This is a useful reference for the policy/building code makers for heating and cooling strategies of this region.

- The method could be applied to any other regions. Weather station data used provide insight for areas but any specific site.

\section{Acknowledgement}

The research work is based on the UK-China collaborative research project 'Low carbon climate-responsive Heating and Cooling of Cities (LoHCool)' supported by the National Natural Science Foundation of China [NSFC Grant No. 51561135002] and the UK Engineering and Physical Sciences Research Council [EPSRC Grant No. EP/N009797/1]. The research is associated with the China National Key R\&D Programme 'Solutions to Heating and Cooling of Buildings in the Yangtze River Region' [Grant No: 2016YFC0700300]. Mr Jie Xiong would like to thank the China Scholarship Council for its financial support as a sponsored researcher at the University of Reading [Grant No: 201706050009] and Miss Xingxing Wu for her assistant in weather data collection. 


\section{References}

[1] Intergovernmental Panel on Climate Change. Climate Change 2013: The Physical Science Basis. Cambridge: Cambridge University Press; 2013.

[2] Crowley TJ. Causes of Climate Change Over the Past 1000 Years. Science (80- ) 2000;289:270-7. doi:10.1126/science.289.5477.270.

[3] Qu W, Xu L, Qu G, Yan Z, Wang J. The impact of energy consumption on environment and public health in China. Nat Hazards 2017;87:675-97. doi:10.1007/s11069-017-2787-5.

[4] Rafindadi AA, Yusof Z, Zaman K, Kyophilavong P, Akhmat G. The relationship between air pollution, fossil fuel energy consumption, and water resources in the panel of selected Asia-Pacific countries. Environ Sci Pollut Res 2014;21:11395-400. doi:10.1007/s11356-014-3095-1.

[5] ChinaDaily. Full text of President Xi's speech at opening ceremony of Paris climate summit 2015. http://africa.chinadaily.com.cn/2015-12/01/content_22592476.htm (accessed March 15, 2018).

[6] EU. Directive 2010/31/EU of the European Parliament and of the Council of 19 May 2010 on the energy performance of buildings. Off J Eur Union 2010;L153:13-35.

[7] Building energy conservation research center of Tsinghua University. Annual Research Report on the Development of Building Energy Conservation in China 2017. Beijing: China Architecture \& Building Press; 2017.

[8] Yao R, Steemers K, Li B. Introduction to sustainable urban and architectural design. Introd. to Sustain. Urban Archit. Des., Beijing: China Architecture and Building Press; 2006.

[9] Lam JC, Wan KKW, Tsang CL, Yang L. Building energy efficiency in different climates. Energy Convers Manag 2008;49:2354-66. doi:10.1016/j.enconman.2008.01.013.

[10] Cai Z, Yin Y, Wennerstern R. From energy efficiency to integrated sustainability in housing development in China: a case study in a hot-summer/cold-winter zone in China. J Hous Built Environ 2013;28:329-44. doi:10.1007/s10901-012-9316-3.

[11] Feng Y. Thermal design standards for energy efficiency of residential buildings in hot summer/cold winter zones. Energy Build 2004;36:1309-12. doi:10.1016/j.enbuild.2003.08.003.

[12] Schnieders J, Feist W, Rongen L. Passive Houses for different climate zones. Energy Build 2015;105:71-87. doi:10.1016/j.enbuild.2015.07.032.

[13] Krarti M, Ihm P. Evaluation of net-zero energy residential buildings in the MENA region. Sustain Cities Soc 2016;22:116-25. doi:10.1016/j.scs.2016.02.007.

[14] Gaglia AG, Tsikaloudaki AG, Laskos CM, Dialynas EN, Argiriou AA. The impact of the energy performance regulations' updated on the construction technology, economics and energy aspects of new residential buildings: The case of Greece. Energy Build 2017;155:225-37. doi:10.1016/j.enbuild.2017.09.008.

[15] Özkan DB, Onan C. Optimization of insulation thickness for different glazing areas in buildings for various climatic regions in Turkey. Appl Energy 2011;88:1331-42. doi:10.1016/j.apenergy.2010.10.025.

[16] Yang L, Lam JC, Tsang CL. Energy performance of building envelopes in different climate zones in China. Appl Energy 2008;85:800-17. doi:10.1016/j.apenergy.2007.11.002.

[17] Wang Y, Chen Y, Zhou J. Dynamic modeling of the ventilated double skin façade in hot summer and cold winter zone in China. Build Environ J 2016;106:365-77. 
doi:http://dx.doi.org/10.1016/j.buildenv.2016.07.012.

[18] Jaber S, Ajib S. Thermal and economic windows design for different climate zones. Energy Build 2011;43:3208-15. doi:10.1016/j.enbuild.2011.08.019.

[19] Hamdaoui S, Mahdaoui M, Allouhi A, El Alaiji R, Kousksou T, El Bouardi A. Energy demand and

\section{8;188:113-24. doi:10.1016/j.jclepro.2018.03.298.}

[20] Yao R, Li B, Steemers K, Short A. Assessing the natural ventilation cooling potential of office buildings in different climate zones in China. Renew Energy 2009;34:2697-705. doi:10.1016/j.renene.2009.05.015.

[21] Li Y, Li X. Natural ventilation potential of high-rise residential buildings in northern China using coupling thermal and airflow simulations. Build Simul 2015;8:51-64. doi:10.1007/s12273-014-0188-1.

[22] Tan Z, Deng X. Assessment of Natural Ventilation Potential for Residential Buildings across Different Climate Zones in Australia. Atmosphere (Basel) 2017;8:1-17. doi:10.3390/atmos8090177.

[23] Babaizadeh H, Haghighi N, Asadi S, Broun R, Riley D. Life cycle assessment of exterior window shadings in residential buildings in different climate zones. Build Environ 2015;90:168-77. doi:10.1016/j.buildenv.2015.03.038.

[24] Singh R, Lazarus IJ, Kishore VVN. Uncertainty and sensitivity analyses of energy and visual performances of office building with external venetian blind shading in hot-dry climate. Appl Energy 2016;184:155-70. doi:10.1016/j.apenergy.2016.10.007.

[25] He Z. Chinese national standards for application of solar thermal technology in civil buildings. Energy Procedia 2015;70:347-52. doi:10.1016/j.egypro.2015.02.133.

[26] The Ministry of Housing and Urban-Rural Development of the People's Republic of China. GB 50189-2005 Design standard for energy efficiency of public buildings. Beijing: China Architecture \& Building Press; 2005.

[27] The Ministry of Housing and Urban-Rural Development of the People's Republic of China. JGJ 134-2010 Design standard for energy efficiency of residential buildings in hot summer and cold winter zone. Beijing: China Architecture \& Building Press; 2010.

[28] Ministère de l'Environnement de l'Énergie et de la Mer. Réglementation Thermique 2012. 2012.

[29] The Ministry of Housing and Urban-Rural Development of the People's Republic of China. GB 50176-2016 Code for thermal design of civil building. Beijing: China Architecture \& Building Press; 2016.

[30] The Ministry of Housing and Urban-Rural Development of the People's Republic of China. GB 50176-93 Thermal design code for civil building. Beijing: China Planning Press; 1993.

[31] ASHRAE. ANSI/ASHRAE Standard 169-2013 Climatic Data for Building Design Standards. Atlanta: ASHRAE; 2013.

[32] California Energy Commission. California Energy Maps - California Building Climate Zone Areas 2015. http://www.energy.ca.gov/maps/renewable/building_climate_zones.html (accessed November 15, 2017).

[33] Hall VT, Deter ER. California climate zone descriptions for new buildings. Sacramento, California: California Energy Commission; 1995.

[34] Australia Building Codes Board. NCC 2016 Building Code of Australia - Volume One. Canberra: Australia Building Codes Board; 2016.

[35] Department of the Environment and Energy. Nation House Energy Rating Scheme - Climate Zone Map 2012. http://www.nathers.gov.au/sites/all/themes/custom/nathers_2016/climate-map/index.html (accessed 
March 16, 2017).

[36] NatHERS National Administrator. Nationwide House Energy Rating Scheme (NatHERS) Software Accreditation Protocol. 2012.

[37] Yao R, Costanzo V, Li X, Zhang Q, Li B. The effect of passive measures on thermal comfort and

\section{Build Eng 2018;15:298-310. doi:10.1016/j.jobe.2017.11.012.}

energy conservation. A case study of the hot summer and cold winter climate in the Yangtze River region. J

[38] Givoni B. Man, Climate and Architecture. 2nd ed. London: Applied Science Publishers; 1969.

[39] Jacobeit J. Classifications in climate research. Phys Chem Earth 2010;35:411-21. doi:10.1016/j.pce.2009.11.010.

[40] Köppen W. Die Klimate der Erde (Climates of the Earth). Berlin: 1923.

[41] Kottek M, Grieser J, Beck C, Rudolf B, Rubel F. World map of the Koppen-Geiger climate classification updated. Meteorol Zeitschrift 2006;15:259-63. doi:10.1127/0941-2948/2006/0130.

[42] Olgyay V. Design with Climate: Bioclimatic Approach to Architectural Regionalism. Princeton: Princeton University Press; 2015.

[43] Walsh A, Cóstola D, Labaki LC. Comparison of three climatic zoning methodologies for building energy efficiency applications. Energy Build 2017;146:111-21. doi:10.1016/j.enbuild.2017.04.044.

[44] Institute for Building Environment and Energy Conservation. Regional classification according to judgment criteria of housing industry 2013. http://ees.ibec.or.jp/documents/ (accessed July 16, 2017).

[45] Bureau of Energy Efficiency. Energy Conservation Building Code User Guide. New Delhi: Bureau of Energy Efficiency; 2013.

[46] Ali S, Sharma M, Maiteya V. Climatic classification for building design in India. Archit Sci Rev 1993;36:31-4. doi:https://doi.org/10.1080/00038628.1993.9696730.

[47] Spanish Ministry of Public Service. Documento Básico DB-HE Ahorro de Energía. Código Técnico la Edif., 2013, p. 67137-209.

[48] de la Flor FJS, Lissén JMS, Domínguez SÁ. A new methodology towards determining building performance under modified outdoor conditions. Build Environ 2006;41:1231-8. doi:10.1016/j.buildenv.2005.05.035.

[49] Salmerón JM, Álvarez S, Molina JL, Ruiz A, Sánchez FJ. Tightening the energy consumptions of buildings depending on their typology and on Climate Severity Indexes. Energy Build 2013;58:372-7. doi:10.1016/j.enbuild.2012.09.039.

[50] Agence Nationale pour le Developpement des Energies Renouvelables et de l'Efficacite Energetique Maroc. Les éléments techniques du projet de la réglementation thermique du bâtiment au Maroc. 2011.

[51] Wan KKW, Li DHW, Yang L, Lam JC. Climate classifications and building energy use implications in China. Energy Build 2010;42:1463-71. doi:10.1016/j.enbuild.2010.03.016.

[52] Lau CCS, Lam JC, Yang L. Climate classification and passive solar design implications in China. Energy Convers Manag 2015;48:2006-15. doi:10.1016/j.enconman.2007.01.004.

[53] Walsh A, Cóstola D, Labaki LC. Review of methods for climatic zoning for building energy efficiency programs. Build Environ 2017;112:337-50. doi:10.1016/j.buildenv.2016.11.046.

[54] The Chartered Institution of Building Services Engineers. Degree-days: Theory and Application. London: The Chartered Institution of Building Services Engineers; 2006.

[55] Bessec M, Fouquau J. The non-linear link between electricity consumption and temperature in 
Europe: A threshold panel approach. Energy Econ 2008;30:2705-21. doi:10.1016/j.eneco.2008.02.003.

[56] Dash PK, Gupta NC, Rawat R, Pant PC. A novel climate classification criterion based on the performance of solar photovoltaic technologies. Sol Energy 2017;144:392-8. doi:10.1016/j.solener.2017.01.046.

[57] Ministerio de Fomento e IDAE. Fundamentos Te' cnicos de la Calificación n Energé tica de Viviendas. Centro de Publicaciones Secretarı'a General Te' cnica Ministerio de Fomento; 1999.

[58] Verichev K, Carpio M. Climatic zoning for building construction in a temperate climate of Chile. Sustain Cities Soc 2018;40:352-64. doi:10.1016/j.scs.2018.04.020.

[59] Jain AK, Murty MN, Flynn PJ. Data clustering: a review. ACM Comput Surv 1999;31:264-323. doi:10.1145/331499.331504.

[60] Mahajan M, Nimbhorkar P, Varadarajan K. The planar k-means problem is NP-hard. Theor Comput Sci 2012;442:13-21. doi:10.1016/j.tcs.2010.05.034.

[61] Fovell RG, Fovell M-YC. Climate Zones of the Conterminous United States Defined Using Cluster Analysis. J Clim 1993;6:2103-35. doi:10.1175/1520-0442(1993)006<2103:CZOTCU>2.0.CO;2.

[62] Dezfuli AK. Spatio-temporal variability of seasonal rainfall in western equatorial Africa. Theor Appl Climatol 2011;104:57-69. doi:10.1007/s00704-010-0321-8.

[63] Manning CD, Raghavan P, Schutze H. An Introduction to Information Retrieval. Inf Retr Boston 2009:1-18. doi:10.1109/LPT.2009.2020494.

[64] Ward JH. Hierarchical Grouping to Optimize an Objective Function. J Am Stat Assoc 1963;58:236-44. doi:10.1093/comjnl/26.4.354.

[65] Murtagh F. A Survey of Recent Advances in Hierarchical Clustering Algorithms. Comput J 1983;26:354-9.

[66] Badr HS, Zaitchik BF, Dezfuli AK. A tool for hierarchical climate regionalization. Earth Sci Informatics 2015;8:949-58. doi:10.1007/s12145-015-0221-7.

[67] Baeriswyl P -a., Rebetez M. Regionalization of precipitation in Switzerland by means of principal component analysis. Theor Appl Climatol 1997;58:31-41. doi:10.1007/BF00867430.

[68] Gong X, Richman MB. On the Application of Cluster Analysis to Growing Season Precipitation Data in North America East of the Rockies. J Clim 1995;8:897-931. doi:10.1175/15200442(1995)008<0897:OTAOCA>2.0.CO;2.

[69] Walsh A, Cóstola D, Chebel L. Performance-based validation of climatic zoning for building energy e ffi ciency applications. Appl Energy 2018;212:416-27. doi:10.1016/j.apenergy.2017.12.044.

[70] Li B, Du C, Yao R, Yu W, Costanzo V. Indoor thermal environments in Chinese residential buildings responding to the diversity of climates. Appl Therm Eng 2018;129:693-708. doi:10.1016/j.applthermaleng.2017.10.072.

[71] Cao B, Luo M, Li M, Zhu Y. Too cold or too warm? A winter thermal comfort study in different climate zones in China. Energy Build 2016;133:469-77. doi:10.1016/j.enbuild.2016.09.050.

[72] Li DHW, Yang L, Lam JC. Impact of climate change on energy use in the built environment in different climate zones - A review. Energy 2012;42:103-12. doi:10.1016/j.energy.2012.03.044.

[73] Cao J, Li M, Wang M, Xiong M, Meng F. Effects of climate change on outdoor meteorological parameters for building energy-saving design in the different climate zones of China. Energy Build 2017;146:65-72. doi:10.1016/j.enbuild.2017.04.045.

[74] Shi P, Sun S, Wang M, Li N, Wang J, Jin Y, et al. Climate change regionalization in China (1961- 
2010). Sci China Earth Sci 2014;57:2676-89. doi:10.1007/s11430-014-4889-1.

[75] Erba S, Causone F, Armani R. The effect of weather datasets on building energy simulation outputs. Energy Procedia 2017;134:545-54. doi:10.1016/j.egypro.2017.09.561.

[76] China Meteorological Administration. Dataset of Daily Surface Observation Data in China. China Meteorol Data Serv Cent n.d. http://data.cma.cn/data/cdcdetail/dataCode/SURF_CLI_CHN_MUL_DAY_V3.0.html (accessed July 1, 2017).

[77] China Meteorological Administration. Dataset of Daily Solor Radiation in China. China Meteorol Data Serv Cent n.d. http://data.cma.cn/data/cdcdetail/dataCode/RADI_MUL_CHN_DAY.html (accessed July 1, 2017).

[78] General Administration of Quality Supervision Inspection and Quarantine of the People's Republic of China (AQSIQ). GB/T 35221-2017 Specifications for surface meteorological observation - General. Beijing: Standards Press of China; 2017.

[79] U.S. Dept. of Energy. EnergyPlus ${ }^{\mathrm{TM}}$ Version 8.4.0 Documentation - Engineering Reference. 2016.

[80] Chartered Institution of Building Services, Engineers (CIBSE). CIBSE Guide A: Environmental design. Norfolk: Page Bros. (Norwich) Ltd.; 2015.

[81] Li Y, Zhang G, Lv GZ, Zhang AN, Wang RZ. Performance study of a solar photovoltaic air conditioner in the hot summer and cold winter zone. Sol Energy 2015;117:167-79. doi:10.1016/j.solener.2015.04.015.

[82] Kent CW, Lee K, Ward HC, Hong J-W, Hong J, Gatey D, et al. Aerodynamic roughness variation with vegetation: analysis in a suburban neighbourhood and a city park. Urban Ecosyst 2018;21:227-243. doi:https://doi.org/10.1007/s11252-017-0710-1.

[83] Heumann C, Schomaker M, Shalabh. Introduction to Statistics and Data Analysis. 1st ed. Basel: Springer International Publishing; 2016.

\section{Appendix}

Table A.1: Sub-zones for building energy efficiency in the Hot Summer and Cold Winter zone of China

\begin{tabular}{|c|c|c|c|c|c|c|c|c|c|}
\hline Province & City & WMO reference & $\begin{array}{c}\text { Latitude } \\
\left({ }^{\circ} \mathbf{E}\right)\end{array}$ & $\begin{array}{c}\text { Longitude } \\
\left({ }^{\circ} \mathbf{N}\right)\end{array}$ & $\begin{array}{c}\text { Altitude } \\
(\mathbf{m})\end{array}$ & Sub-zone & Humidity & Radiation & Wind \\
\hline Shanghai & Shanghai & 58362 & 121.27 & 31.24 & 5.5 & A2 & $\mathrm{RH} 2$ & Ra1 & WS2 \\
\hline Chongqing & Chongqing & 57516 & 106.28 & 29.35 & 259.1 & $A 3$ & RH1 & Ra3 & WS4 \\
\hline Hubei & Wuhan & 57494 & 114.03 & 30.36 & 23.6 & A1 & RH1 & $\mathrm{Ra} 2$ & WS3 \\
\hline Hubei & Yichang & 57461 & 111.22 & 30.44 & 133.1 & B2 & RH2 & Ra3 & WS4 \\
\hline Hunan & Changsha & 57687 & 112.55 & 28.13 & 68 & A2 & $\mathrm{RH} 2$ & $\mathrm{Ra} 2$ & wS2 \\
\hline Hunan & Hengyang & 57874 & 112.24 & 26.25 & 116.6 & A3 & $\mathrm{RH} 2$ & Ra2 & WS3 \\
\hline Hunan & Xiangxi & 57649 & 109.41 & 28.14 & 208.4 & B2 & RH1 & Ra3 & WS4 \\
\hline Jiangxi & Nanchang & 58606 & 115.55 & 28.36 & 46.9 & A3 & $\mathrm{RH} 2$ & $\mathrm{Ra} 2$ & WS3 \\
\hline Jiangxi & Ji-an & 57799 & 114.55 & 27.03 & 71.2 & A3 & RH1 & $\mathrm{Ra}^{*}$ & WS3 \\
\hline Jiangxi & Ganzhou & 57993 & 115 & 25.52 & 137.5 & A3 & $\mathrm{RH} 2$ & $\mathrm{Ra} 2$ & WS4 \\
\hline Anhui & Hefei & 58321 & 117.18 & 31.47 & 27 & A1 & $\mathrm{RH}_{2}^{*}$ & Ra1 & wS2 \\
\hline
\end{tabular}


